\title{
Os metafilmes do inacabado: rastros e processos de filmes fantasmáticos
}

Felipe Muanis ${ }^{2}$

Peter Bogdanovich: Quando acha que vai poder terminá-lo?

Orson Welles: Vou dar esse título - Quando É Que Você Vai Terminar Don Quixote? [Risadas]. ${ }^{3}$

\section{Introdução}

AO LONGO DA HISTÓRIA DO CINEMA, INÚMEROS FILMES FORAM PRODUZIDOS E FINALIZADOS EM TODO O MUNDO, sendo vistos por um grande público e constituindo obras completas, dignas de estudos e rememorações. Muitos deles, além de apreciados pelas pessoas, são alvos de análises e de investigação da crítica e da academia, pelas razões mais variadas, tanto por seus méritos quanto pelos seus desmerecimentos, no que tange à inovação, à linguagem, à originalidade, à qualidade técnica e ao processo de produção. Estes últimos são importantes para inserir o filme no seu contexto de produção, a fim de possibilitar um entendimento mais amplo com relação às escolhas da equipe e aos resultados do produto. Da ideia inicial ao roteiro e dele à filmagem, o filme é consequência de um processo vivo e dinâmico, assim como todas as artes, o que interfere de forma contundente na obra acabada. É esse percurso sob o qual muitos estudiosos se debruçam para compreender melhor o produto fílmico, alvo da crítica genética, com o fito de tematizar o cinema e de buscar, através da análise de documentos, imagens, ensaios, desenhos de cenário, anotações e rascunhos, reconstituir o processo fílmico que pode exprimir tanto ou mais do filme que a obra em si.

Parte-se, assim, de uma premissa para viabilizar essa metodologia epistemológica que se fundamenta na coleta de rastros, construção e armazenamento de arquivos, tal como faz o historiador ou o antropólogo. Como lembra Cecília Almeida Salles, "são vestígios vistos como testemunho material de uma criação em processo" ${ }^{4}$. Salles reforça ainda a importância de esse testemunho e de esses rastros estarem referenciados a uma obra acabada para que seja possível estabelecer um vetor entre ela e os diversos rastros que definem o seu processo de realização, pois "a obra é, antes de mais nada, o elemento propulsor dos estudos genéticos: se não existisse a obra, não haveria o interesse de compreender seu modo de fabricação" ${ }^{5}$. É a partir dessa premissa que se desenvolve a proposta deste artigo: é possível fazer o estudo

\footnotetext{
${ }^{1}$ Esse artigo apresenta o estágio inicial de uma investigação no âmbito do grupo de pesquisa Historiografia Audiovisual, vinculado ao PPG Artes, Cultura e Linguagens do Instituto de Artes e Design da Universidade Federal de Juiz de Fora. www.historiografiaaudiovisual.com.br.

${ }^{2}$ Professor de Cinema e do Programa de Pós-Graduação em Artes, Cultura e Linguagens da Universidade Federal de Juiz de Fora. Professor do Programa de Pós-graduação do Programa em Comunicação da Universidade Federal do Ceará.

${ }^{3}$ Bogdanovich, P. Este é Orson Welles. São Paulo: Globo, 1995, p.144.

${ }^{4}$ SALLES, C. A. Gesto inacabado: processo de criação artística. São Paulo: FAPESP: Annablume, 1998, p.18.

${ }^{5}$ SALLES, C. A. Imagens em construção. In: Revista Olhar. Ano 2, no 4, Dez; 2000, p. 3.
} 
genético tendo como referência uma obra que não existe? Mais do que isso, é possível que um outro filme possa ser em si um estudo genético sobre um filme inexistente? Quais contribuições essas obras podem trazer para a crítica genética?

Essa reflexão parte de uma observação não incomum: inúmeros filmes na história do cinema que simplesmente não foram terminados ou finalizados não constituem, consequentemente, uma obra acabada ${ }^{6}$. Contudo, ainda que não tenham sido terminados, alguns desses filmes deixaram rastros suficientes para ganhar relevância e ter seus processos investigados, muitas vezes até mesmo para gerar outros filmes historiográficos que tematizam o próprio filme e o próprio cinema. Nesse sentido, busca-se aqui apresentar o conceito de filmes fantasmáticos para o ponto de partida dessa discussão que ora se apresenta.

Filmes fantasmáticos são todos aqueles filmes que foram interrompidos em qualquer estágio da produção e que impõem para o crítico ou o espectador a necessidade de serem idealizados. Ou seja, o filme fantasmático, por mais que eventualmente possa ser até finalizado posteriormente por outras pessoas e existir concretamente, sempre será uma obra incompleta, inacabada, por ter existido apenas mentalmente na imaginação de seus realizadores. É importante reforçar que não se faz aqui referências apenas à figura do diretor como realizador único, mas de toda a equipe, o que não traz uma ideia de unidade, mas de várias versões fantasmáticas de um mesmo filme. O filme fantasmático é uma abstração, é uma possibilidade do porvir de um filme que nunca se realizou. A fim de resgatar seus rastros e poder retornar a ele, é necessário voltar ao processo criador para se chegar ao gesto inacabado, como teorizado por Cecília Salles.

A hipótese que se busca comprovar com este artigo, portanto, é a de que certos filmes podem se constituir como crítica genética de uma obra inexistente - os filmes fantasmáticos - e que, com isso, podem ganhar um duplo papel, tanto de estudo genético quanto, ao mesmo tempo, de obra, apontando para sua singularidade: a ideia de um metafilme. Dessa maneira, põe-se em dúvida a afirmação de que o estudo genético se limita apenas à obra acabada, mas que pode se estender a obras inexistentes desde que elas tenham deixado rastros: documentação e material suficientes de seu processo para que sua investigação possa ser realizada. Mais do que isso, obras inacabadas ainda permitem a percepção do seu movimento criador, ou seja, de suas "cadeia infinita de agregações”, conforme define Salles (1998, p. 25), o que reforça ainda não se considerar apenas as criações que os artistas efetivamente finalizaram como obras de arte mas também aquelas em processo.

Para tanto, como ponto de partida desta pesquisa, é necessário categorizar ao menos três tipos de filmes fantasmáticos, para se chegar a uma análise crítica de um metafilme como os estudos de crítica genética. Dessa forma, propõe-se nesse texto esmiuçar as categorias dos filmes fantasmáticos apresentando também suas categorias preliminares como os filmes esboço, os filmes sobre filmes e os filmes híbridos. Parte-se aqui de um entendimento sobre a necessidade de se dar mais atenção e de consolidar os filmes inacabados como objeto de análise epistemológica, o que se mostra ainda incipiente no campo teórico do cinema. Para além de incontáveis filmes que podem ser trabalhados nessa chave ${ }^{7}$ e que

\footnotetext{
${ }^{6}$ Importante reforçar que não se desenvolve, aqui, a apropriada proposta conceitual de obra inacabada de Cecília Salles, que questiona a ideia de obra acabada, uma vez que toda a obra acabada para a autora é, em si, uma obra sempre inacabada e incompleta. Ainda que essa proposta seja importante para a crítica genética, para fins metodológicos, o foco deste trabalho são filmes que de uma forma ou outra não puderam ser concretamente terminados conforme planejados inicialmente: ou foram concluídos por outras pessoas, ou se tornaram outro filme.

${ }^{7}$ Há inúmeros filmes que oferecem uma continuidade e indicam a fertilidade desse viés de análise, como o importante Que viva México! (1932), de Sergei Eisenstein, o filme The Other side of the Wind (2018), do próprio Orson Welles. No Brasil há também bons
} 
se adequam a essa análise, destacam-se neste artigo sobretudo alguns trabalhos dos cineastas Orson Welles e Eduardo Coutinho que não apenas faziam metafilmes, como viveram obras fantasmáticas. Espera-se, assim, que essa reflexão possa contribuir com novas variáveis epistemológicas para os crítica genética que tematizam o cinema.

\section{Oque resta dos filmes fantasmáticos}

Para buscar e categorizar os filmes que tematizam obras fantasmáticas, é necessário fazer uma distinção entre eles, uma vez que podem se dividir entre filmes esboços, filmes sobre obras inacabadas que evidenciam o processo fílmico e, por fim, filmes híbridos, que reúnem, em si, simultaneamente, os dois modelos anteriores. Essas categorias partem de uma distinção objetiva entre filmes que são finalizados por outra equipe de produção - e efetivamente existem - e filmes que tematizam o contexto e o processo de produção do filme inacabado. Ambos partem de anotações e material fílmico do que foi deixado inconcluso e são resultado, inevitavelmente, de uma recuperação dos materiais, documentos, imagens e testemunhos, para que possam efetivar um filme a partir daí. Esse material engloba desde anotações, boletins de pré-produção, produção e mesmo finalização; fotografias, roteiros, desenhos e ainda as próprias considerações e análises não apenas do diretor como de toda a equipe; a eventuais trocas de correspondências que se mostram imprescindíveis para reconstruir os rastros do filme fantasmático. Ou seja, ambas as maneiras de abordar um filme fantasmático a partir de outro filme derivam de uma inevitável investigação genética para que, ao ter acesso aos documentos e às imagens filmadas, possa se desvendar parte do seu processo e dele se chegar à obra. Nesse sentido, tais práticas fílmicas se equivalem ao exercício da crítica genética. A única diferença é que esses filmes não partem de uma obra acabada, mas sim da idealização de um filme e que, por isso, resultam apenas em uma obra possível da qual é impraticável uma integridade plena com o filme fantasmático a que se refere, constituindo com ele apenas uma aproximação mais ou menos fiel. Dessa maneira, é justamente uma prática de investigação genética que resulta no filme - normalmente um documentário - que se referencia à obra inacabada, independentemente da categoria de abordagem acima mencionada que for escolhida.

Assim, uma categoria contempla um filme retomado e se concretiza da forma possível a partir do material encontrado mais os acréscimos da nova equipe de realizadores. Já a outra categoria é uma reflexão fílmica sobre o filme fantasmático e evidencia em imagens as marcas, os elementos e os documentos do processo fílmico que restaram como rastros do processo da obra inacabada. Ambas as estratégias têm o filme fantasmático como referente, mesmo o filme que se concretiza parcialmente a posteriori, com o material encontrado e trabalhado por outra equipe de produção - o que aqui será chamado de filme esboço. Torna-se, assim, o filme possível dentro de uma perspectiva mais ampla de um filme fantasmático, inacabado, que efetivamente não se completou enquanto obra. Dessa maneira, o fantasmático, quando retomado, de uma forma ou outra, está sempre associado a essa ideia de um filme possível, pois carrega em si a limitação trazida pela interrupção do processo de produção, o que o transforma invariavelmente em outra obra. Nesse sentido, é indispensável trazer alguns casos que ilustrem as categorias dos filmes realizados a partir de um filme fantasmático e, portanto, inexistente como referente.

exemplos como o Onde a terra acaba (2002), de Sérgio Machado, Já visto, jamais visto (2013), de Andrea Tonacci, O roteiro do gravador (1967) de Sylvio Lanna e Forofina, um filme a ser feito (2020), de Sylvio Lanna e Cavi Borges. 


\subsection{Filmes esboço}

Um oportuno exemplo de filme esboço, ou seja, de uma obra inacabada retomada posteriormente e finalizada com o material disponível por outro realizador ou por outra equipe é o Don Quixote de Orson Welles (1992). O projeto original de Welles, iniciado em 1955, mostrava Don Quixote (Francisco Reiguera) e Sancho Pança (Akim Tamiroff) perambulando pela Espanha na década de 1960. Filmado gradativamente ao longo de dez anos como um exercício pessoal do diretor, foi feito aos poucos e sem pressa, nos momentos em que Welles tinha disponibilidade eventual e conseguia reunir a equipe. Quando o cineasta morreu em 1985, o filme continuava inacabado, apesar de haver muito material filmado.

Esse filme foi retomado posteriormente, produzido por Patxi Irigoyen e montado por Jess Franco, assistente de direção de Welles e diretor de segunda unidade do filme. Essa proximidade proporcionaria, em tese, um entendimento mais próximo sobre as escolhas de Welles a partir de suas ideias originais que poderiam ser seguidas na versão final do filme de 1992. Contudo, de acordo com o crítico espanhol Juan Cobos, que assistiu a um corte do filme ainda quando Welles o filmava, a versão de Franco foi por um caminho distinto. Além disso, algumas imagens filmadas por Welles não puderam ser utilizadas no filme por já se encontrarem em coleções privadas ${ }^{8}$. Portanto, mesmo com a proximidade entre Welles e Franco e do filme ter efetivamente sido finalizado posteriormente, ele continua sendo um filme derivado, o que o referencia a um filme fantasmático que não foi efetivamente completado no seu processo convencional de produção e enfrentou algumas limitações.

Apesar de o filme ser tributário da linguagem e da estética moderna, características do cinema de Orson Welles, há nele elementos que sugerem a ideia de inacabado em função de certa descontinuidade estética: alguns planos apresentam problemas de iluminação e subexposição, contraste e foco, e se assemelham mais a planos que não funcionaram e por isso precisariam ser refeitos, a planos que seriam utilizados como estavam, sobretudo ao se pensar a qualidade plástica e o rigor técnico habitual dos filmes de Welles. O filme parece, nessa perspectiva, tornar claramente visíveis algumas marcas do processo que evidenciam o conceito de estética do inacabado de Salles ${ }^{9}$ e que, na maioria das vezes, soam imperceptíveis para o espectador fílmico.

Percebe-se assim, que Franco e Irigoyen aparentemente priorizaram suas concepções do filme na montagem à estrutura do filme pensada originalmente por Orson Welles, conforme sugere Cobos ${ }^{10}$. Talvez a seleção e a utilização de algumas imagens que evidenciam uma estética do inacabado e que, em situações normais, seriam descartadas no processo de montagem e/ou refilmadas, corroborem isso. É como se o filme acabado, derivado do filme fantasmático de Welles, absorvesse para si as próprias imagens rascunho que seriam fundamentais para o estudo genético da obra e para entender o seu percurso de produção. Dessa maneira, essas imagens mudam de caráter e se tornam elementos constitutivos do filme: são revalorizadas e ganham novas complexidades, como se verá mais à frente neste artigo.

\footnotetext{
${ }^{8}$ Ver https://www.imdb.com/title/tt0104121/trivia/?ref_=tt_qL_trv . Acesso em 13 de outubro de 2021.

${ }^{9}$ De acordo com Cecília Salles (2000, p.1-2), "como cada etapa do processo contém, potencialmente, um objeto acabado e o objeto considerado acabado representa, também de forma potencial, um momento do processo, pode-se falar em uma estética do inacabado, da imperfeição ou da busca por perfeição."

${ }^{10}$ Ibidem.
} 
Essas imagens, aparentemente ineficientes, trazem para o filme não apenas a sensação de algo que estava em processo e ficou inacabado mas também dialogam com a ideia de coeficiente artístico de Duchamp ${ }^{11}$, em que a arte residiria justamente na diferença entre o que se efetiva na obra pronta em detrimento ao que foi originalmente planejado ${ }^{12}$. Por mais que Duchamp aparentemente não especificasse essa relação quando a obra é continuada por outro realizador e se ativesse a um movimento interno da prática de um mesmo artista, essas imagens inacabadas do filme de Welles, uma vez aproveitadas na montagem de Franco, também carregam um coeficiente artístico de segunda ordem, o que o reforça também como outro filme e o afasta do filme fantasmático original.

Pelo prisma da teoria de Duchamp, poderia se concluir que qualquer filme acabado faz referência a um filme de origem que sempre será fantasmático, pois não foi realizado tal e qual pensado, mas acumulou elementos outros, imprevistos, alguns trazidos pelo acaso, que constituiriam o coeficiente artístico do filme e que marcariam indelevelmente sua versão final. No mesmo diapasão, seria possível pensar, até mesmo tomando como referência a valorização que Baudelaire ${ }^{13}$ faz dos esboços rápidos e da imagem inacabada de Constantin Guys em Sobre a Modernidade, no potencial dessas imagens em um filme como Don Quixote de Orson Welles. Talvez essas imagens sejam transformadoras e, ao contrário de serem um defeito ou uma ineficiência, agreguem virtudes ao filme fantasmático originariamente planejado.

\subsection{Filmes sobre filmes}

A segunda categoria de filmes que se referenciam em filmes fantasmáticos se ocupa de trabalhos audiovisuais que narram o percurso e o processo de produção de uma obra inacabada; que trazem neles uma série de documentos, imagens filmadas, ensaios, desenhos de cenários e figurinos; e que mostram testemunhos e reuniões de equipe, entre outros. Evidencia-se assim, nesse tipo de obra, uma série de fragmentos documentais do processo de realização do filme de origem, que se enquadram na mesma estratégia da crítica genética e que compreendem a coleta e a análise de material de produção, além do exercício de atentar para o processo da obra à qual se referencia de maneira reveladora. Um exemplo muito comum de filmes sobre filmes são os making-ofs ${ }^{14}$ que podem ser encontrados com frequência em edições em Blu-Ray ou DVD e que trazem ao espectador particularidades dos processos de produção do filme de origem. Nesse sentido, making-ofs poderiam ser entendidos como crítica genética em forma de filme e se associam a obras acabadas, tal como Salles define o pressuposto fundamental dos estudos genéticos. Todavia, há inúmeros exemplos desse tipo de narrativa audiovisual para além dos making-ofs.

\footnotetext{
${ }^{11}$ Duchamp, M. O ato criador. In: Battcock, G. A Nova Arte. São Paulo: Perspectiva, 2002. p. 71-74.

${ }^{12}$ A afirmação de Duchamp dialoga com o entendimento de Cecília Salles (1998, p.39-40) que afirma que "(...) Se o projeto fosse absolutamente explícito e claro ou se houvesse uma pré-determinação, não haveria espaço para desenvolvimento, crescimento e vida; a criação seria, assim, um processo puramente mecânico.”.

espaço para desenvolvimento, crescimento e viela; a criação seria,

${ }^{13}$ Baudelaire, C. Sobre a modernidade. Rio de janeiro: Paz e Terra, 1996, p.32.

${ }^{14}$ Making-of é uma produção audiovisual, normalmente de média-metragem, que tematiza uma produção de cinema específica, muitas vezes realizado com fins de divulgação.
} 
Um dos exemplos curiosamente também tematiza a obra de Cervantes: Perdido em La Mancha (2002), de Keith Fulton e Louis Pepe deveria ser apenas o making-of do filme OHomem que Matou Dom Quixote, dirigido por Terry Gillian, que teve a produção iniciada no ano 2000, interrompida após uma série de percalços. O filme foi retomado apenas em 2017 depois de oito tentativas frustradas, mas em uma nova produção, com outros atores e equipe. Apesar de Terry Gillian ter enfim realizado uma nova versão do filme e o lançado em 2018, Perdido em La Mancha deixou de ser o makingof de um filme e passou a ser um filme sobre um processo fílmico que não se concretizou, uma vez que toda a produção se modificou para a versão definitiva, finalizada 16 anos depois. Desse modo, o documentário de Fulton e Pepe se refere a uma versão de um filme inexistente. É um exemplo contundente do que poderia ser chamado de narrativa genética que tematiza o processo de produção do filme e revela seus bastidores. O documentário funciona, nesse sentido, como um repositório de alguns documentos, desenhos, storyboards, filmagens, trabalho das diferentes equipes, cenários, figurinos, testes de elenco e mecânica de set, além de mostrar os impasses e os problemas que levaram ao cancelamento da produção ${ }^{15}$. O próprio Terry Gillian incentivou os diretores do making-of a torná-lo um documentário, pois "alguém tinha que tirar um filme daquilo"16. Após finalizado, Perdido em La Mancha se revela como um documentário sobre um filme fantasmático em que suas polaridades estão trocadas: se por um lado o filme de referência não existe, por outro o documentário que o tematiza existe e se concretiza simultaneamente como estudo genético de um filme inexistente, como uma obra fílmica em si, acabada. Evidencia-se assim que esse tipo de documentário desponta ao mesmo tempo como filme e estudo genético.

Essa característica não é tributária apenas de filmes que tenham sua origem em um making-of ou o sejam, efetivamente. Inúmeros documentários que tematizam a historiografia de filmes fantasmáticos têm esse caráter ambíguo e indistinto de ser, ao mesmo tempo, obra e estudo genético. Um exemplo é o documentário Shirkers (2018), dirigido por Sandy Tan, que narra a história do filme homônimo inconcluído, porque o diretor de fotografia roubou as latas com o material revelado e o filme nunca foi montado. Tal e qual, Perdido em La Mancha, Shirkers narra os acontecimentos que resultaram no filme interrompido, trazendo também testemunhos, imagens de cenas e filmagens, enfim, parte da documentação que englobaria uma crítica genética do Shirkers original. Nesse caso, o caráter ambíguo do documentário é ainda maior, uma vez que o seu nome é o mesmo do filme original. Ou seja, o filme inacabado continua fantasmático, mas o documentário assume, de certa maneira, sua identidade, como um duplo do filme de origem - ainda que sejam totalmente diferentes. Outro diferencial de Shirkers com relação aos exemplos até agora elencados é que, nesse caso, a diretora do filme fantasmático é a mesma do documentário genético, o que traz um componente autobiográfico fortemente autorreferenciado, resultando determinadas especificidades que podem ser ainda mais bem observadas no documentário brasileiro Cabra Marcado para Morrer (1984), de Eduardo Coutinho.

Em 15 de abril de 1962, após uma entrevista com Elizabeth Teixeira por ocasião de um comício de protesto contra o assassinato de seu esposo João Pedro Teixeira, líder da Liga Camponesa da Paraíba, nasceu a ideia de filmar Cabra Marcado para Morrer. O filme seria sobre a vida e o assassinato de João Pedro, e Coutinho reencenaria sua história contando com os personagens reais, como Elizabeth Teixeira e seus filhos, que representariam seus próprios papéis. Com o acirramento das tensões entre polícias e camponeses na Paraíba - que resultaram em onze mortos - a equipe de

\footnotetext{
${ }^{15}$ Além disso, a própria edição em DVD traz dois discos com muito material adicional que funciona como um repositório genético do filme fantasmático: entrevistas com elenco e equipe, figurinos, storyboard e stills da filmagem, cenas apagadas, entre outros.

${ }^{16}$ Ver https://www.imdb.com/title/tt0308514/trivia/?ref_=tt_ql_trv . Acesso em 13 de outubro de 2021.
} 
Coutinho se desloca para o Engenho Galileia, em Pernambuco, uma comunidade camponesa que tinha conquistado o direito da terra pelo governo. Lá eles decidem filmar a história de João Pedro com o apoio da população local de nãoatores. A única personagem da história real que permaneceria no filme seria Elizabeth Teixeira, que viajou com a equipe para Pernambuco. As filmagens já haviam começado quando eclode o golpe que levou à ditadura civil-militar no Brasil. O engenho é invadido pelo exército, camponeses e dois integrantes da equipe do filme são presos e todo o material filmado que ali se encontrava e equipamentos, inclusive a câmera, foram apreendidos. Nas manchetes de jornais, noticiou-se que foi feita a maior apreensão de armas e material de publicidade comunista de cubanos infiltrados em Pernambuco com filmes que orientavam a guerrilha e o assassinato de opositores reacionários.

Nessa apreensão, toda a documentação do filme foi perdida, com exceção de 8 fotos e do material filmado que havia sido enviado para ser revelado no laboratório do Rio de Janeiro. O próprio roteiro do filme só foi recuperado anos depois. Em 1981, Coutinho retoma o filme, também com o mesmo nome, mas com uma inflexão totalmente diferente. O novo Cabra marcado para morrer não seria apenas a retomada do filme original de onde havia parado, mas enfocaria uma releitura do processo fílmico, abortado em 1964, 17 anos depois. Coutinho transforma um filme que reproduzia um evento real com seus personagens reais em um documentário tanto sobre João Pedro e Elizabeth quanto sobre as pessoas que participaram do elenco em 1964, também sobre o processo fílmico interrompido, inserindo-o em uma discussão historiográfica.

O documentário Cabra Marcado para Morrer, lançado em fim em 1984, é um resgate da memória do filme fantasmático anterior, que entrevista os não atores no filme e mostra o pouco material que restou da produção original. Ao utilizar estratégias do documentário interativo, em diversos momentos, Coutinho aparece nas imagens junto com a equipe, filmando, entrevistando, chegando aos lugares e algumas vezes discutindo o próprio processo fílmico que estava sendo realizado naquele momento. Isso é notório na cena em que Abraão Teixeira, filho mais velho de Elizabeth, na primeira entrevista de sua mãe a Eduardo Coutinho exige que o filme registre a sua revolta contra todos os sistemas de governo, "que nenhum presta para o pobre"17, a quem Coutinho tranquiliza, informando que tudo será registrado. No documentário de 1984, o pouco material que restou do filme é mostrado e Coutinho, que narra o filme junto ao poeta Ferreira Gullar e ao ator Tite de Lemos, faz especificações precisas, por exemplo, dizendo que uma das imagens foi feita três vezes, que outra foi a última filmada antes da chegada do exército, ou outra da família chegando aonde seria aplicado o título do filme. Ele exibe essas cenas para a população de Engenho Galileia, que viram pela primeira vez as imagens do filme não finalizado em que trabalharam 17 anos antes.

Coutinho não apenas resgata os poucos documentos restantes de seu filme fantasmático, mas narra todo o percurso e toda a trajetória do Cabra marcado para morrer fantasmático, inclusive trazendo os testemunhos de seus participantes, não apenas sobre suas impressões do filme, mas de suas próprias vidas. Novamente, o filme que faz um esforço de reflexão genética de um filme fantasmático ganha centralidade a partir de um filme inexistente que, ao tomar o nome e tematizar o primeiro filme, torna-se um duplo do primeiro, ainda que não seja exatamente uma cópia já que o filme inacabado é um tema central.

É curioso que em Cabra Marcado para Morrer há uma espiral de filmes fantasmáticos, uma vez que houve duas versões do filme idealizadas e abandonadas: a primeira, que seria realizada na Paraíba com os personagens reais da história de

${ }^{17}$ Cabra Marcado para Morrer, 28 minutos e 15 segundos. 
João Pedro, e a segunda, filmada em Pernambuco, no Engenho Galileia, com camponeses como atores, fazendo-se passar pelas personagens reais. Nesse sentido há não apenas dois filmes fantasmáticos referenciando a obra de Coutinho que enfim foi finalizada em 1984 mas também uma sobreposição de documentação genética de dois filmes fantasmáticos para além do próprio documentário terminado. No caso de Coutinho, os filmes fantasmáticos de Cabra Marcado para Morrer são um pretexto para entender como viviam e onde estavam aquelas pessoas e como elas perceberam o processo fílmico abortado em 1964.

Em comum a esses filmes que falam de outros filmes, sejam making-ofs ou documentários, está a característica de se narrar o processo fílmico de um - ou mais - filme fantasmático, a partir de uma experiência incontornável de pesquisa genética dos documentos de produção sobre imagens, depoimentos, ensaios, desenhos. Nesse sentido, parece claro que esse cinema, ao contrário da primeira categoria de filme esboço em que o filme é apenas retomado e finalizado por outra equipe, não se limita a marcas fílmicas que deduzem e evidenciam um processo. Ele chama o espectador para a superfície, como teoriza Ismail Xavier ${ }^{18}$, mas traz em si elementos constitutivos que revelam o percurso de seu processo de produção. Nesse aspecto, pode-se dizer que essas experiências são uma concretização da crítica genética dentro de uma própria obra autorreferente em que o cinema fala de si próprio, em que o discurso de análise é feito através do próprio cinema e, mais do que isso, em que o referente é uma obra inacabada, um filme que não existe. O estudo então, uma vez concretizado, ocupa o lugar de filme de referência sob o qual poderá dele também se constituir uma pesquisa genética posterior.

Esses estudos são importantes e se deve retornar aqui a Raymond Bellour ${ }^{19}$ pela necessidade e rara possibilidade de estudos de cinema serem realizados dentro de uma própria estrutura fílmica. Na perspectiva da reflexão dentro do filme é que cabe ainda a discussão de uma última categoria em que esses dois modelos se misturam.

\subsection{Filmes híbridos}

Ao incauto pode parecer que a categoria de filmes híbridos não acrescentaria nada de novo ao que já foi discutido e à reflexão que ora se desenvolve. Na prática, são obras que reorganizam o material de um filme fantasmático tal como um filme esboço, mas, ao mesmo tempo, fazem uma reflexão sobre o processo fílmico. A junção dessas duas categorias em uma mesma obra potencializa a análise e a compreensão do filme inacabado, pois uma estratégia sustenta a outra. Para o espectador, ver uma cena no filme fantasmático montado posteriormente, associado com discussão ou com fotos do processo fílmico que evidencia o processo, afasta-o da diegese mais simples. Esses dois discursos na mesma obra fazem com que a espectatorialidade do filme esboço seja necessariamente mediada pelo seu próprio processo de filmagem, tornando um indissociável do outro. Constitui-se assim, uma forma mais contundente de perceber não apenas o processo de produção que conduz a obra, como o movimento oposto em que se percebe com mais clareza o que teria sido adicionado ao filme esboço pela nova equipe de realização e que, por diferentes e inúmeros motivos, não estaria presente na versão original.

\footnotetext{
${ }^{18}$ Xavier, I. O discurso cinematográfico: a opacidade e a transparência. Rio de Janeiro: Paz e Terra, 1977.

${ }^{19}$ Bellour, R. L'analyse du film. Paris: Albatros, 1979, p. 29.
} 
Para tanto, seria oportuno retornar a mais um exemplo de Orson Welles, o filme It's all true - Based on an unfinished film by Orson Welles (1993). O documentário traça o percurso de Orson Welles e sua vinda à América do Sul em 1942, um ano depois do lançamento de Cidadão Kane, por sugestão de Nelson Rockfeller, como parte da política de boavizinhança do presidente estadunidense Franklin Roosevelt. Welles filmaria um travelogue em episódios com três histórias, sendo que as duas primeiras seriam filmadas no Brasil: o primeiro episódio se chamaria "Jangadeiros" e mostraria a história dos jangadeiros do Ceará que em 1941 percorreram 1650 milhas da costa brasileira para reivindicar ao Presidente Getúlio Vargas, no Rio de Janeiro, melhores condições trabalhistas para pescadores. O segundo episódio se chamaria "The story of samba" e seria filmado no Rio de Janeiro; e o último episódio, "My friend Bonito", este dirigido por Norman Foster, seria uma adaptação de uma história de Robert Flaherty sobre a amizade entre um menino e um touro e se passaria no México. Durante a filmagem de cenas do que seria o primeiro episódio, o jangadeiro Jacaré morre afogado, o que teria criado em Welles um sentimento de dívida e uma necessidade de terminar o filme. Ele vai ao Ceará e com poucos recursos filma várias cenas em preto e branco, romantizando a história e usando a população como elenco.

De volta aos Estados Unidos, o filme se perde, apesar das inúmeras tentativas de Welles o terminar. A RKO, detentora dos direitos, é vendida para a Desilu que por sua vez é comprada pela Paramount. As 309 latas de filme só foram encontradas décadas depois, em 1985, um pouco antes da morte de Orson Welles que não chegou a ver o material filmado. Muitas tomadas se perderam devido à precariedade na conservação das latas ao longo de mais de 40 anos. Em 1993, 51 anos depois da aventura de Welles pelo Brasil, Richard Wilson, Myron Meisel e Bill Krohn lançam o documentário que conta toda a história de Welles na América do Sul, mostram algumas imagens dos três episódios e montam sua versão da história dos jangadeiros, através de "Four men in a raft", o único episódio que, apesar de provavelmente também não contar com todas as imagens que foram filmadas, conseguiu ganhar uma montagem que oferecia uma coerência narrativa para a história.

É dessa forma que um episódio do filme ganha vida, ainda que não seja precisamente como Welles o tinha pensado. O episódio dos jangadeiros foi filmado originariamente sem som e a versão de Wilson, Meisel e Krohn ganha uma sonorização e trilha-sonora bem-cuidadas, que costuram bem as imagens. Essas, ao contrário das imagens de Don Quixote, apesar de bem mais antigas, apresentam grande qualidade e unidade. O filme ou os episódios fantasmáticos de It's all true continuam operando uma expectativa do que teria sido o filme integral de Welles. Por outro lado, a reelaboração desse material por outros realizadores, somado ao material documental que destrincham o percurso do filme dão uma dimensão nova ao material original. Enquanto o Don Quixote de Orson Welles, carrega marcas conspícuas por causa da diferença entre as imagens, o que apenas sugere adaptações ao projeto original inacabado, elas são apenas indiciais e não trazem em si, informações concretas quanto ao processo do filme fantasmático e mesmo do processo do filme esboço, ocasionando uma incerteza sobre as imagens. Por sua vez, essa indistinção é menor em Four men in a raft, que é lido com mais clareza quanto ao processo do filme fantasmático, pois a versão de 1993 conta com a parte que discute o processo com apoio do material genético do filme inacabado. Essa estrutura permite que, mesmo havendo unidade estética entre suas imagens em que demarcações não são perceptíveis, algumas dessas distinções sejam percebidas durante o visionamento do filme esboço. Nesse sentido, o filme híbrido, que reúne o filme esboço e o filme sobre o filme, apresenta-se como o exemplo mais elaborado de um estudo genético de um filme fantasmático feito no próprio formato fílmico. 


\section{Considerações finais}

A partir das categorias apresentadas sobre os filmes que tematizam filmes fantasmáticos, pode-se concluir que sobretudo os documentários que fazem uma historiografia de um filme inacabado, e os filmes híbridos, que também agregam em si filmes esboço, apresentam possibilidades concretas de se fazer crítica genética ao utilizar o próprio cinema enquanto escritura. Mais do que isso, evidencia-se que a crítica genética nas artes não demanda, necessariamente, referenciar-se em uma obra acabada, conforme apontado por Salles. Pelo contrário, filmes fantasmáticos ou inacabados podem colaborar tanto quanto uma obra existente para o desenvolvimento da crítica genética.

A crítica genética, por sua vez, mostra-se como uma metodologia importante de pesquisa para o cinema, entre outras coisas, justamente por reviver filmes e processos através da análise de documentos e materiais do processo fílmico que são reveladoras e não podem ser abandonados. Por mais que Fayga Ostrower ${ }^{20}$ reforce que os componentes são diferentes do processo em si, esses componentes deixam rastros que viabilizam uma reconstrução parcial do processo e definem a própria história, como escreveu Benjamin ${ }^{21}$. De acordo com Paul Ricoeur ${ }^{22}$, isso acontece com a reconstrução do passado a partir dos rastros deixados para trás, evocados não apenas pelos documentos, mas pela memória presente em testemunhos que fazem parte e que podem ser encontrados em alguns filmes aqui analisados.

Dessa maneira, a reconstrução dos rastros deixados por um filme, mesmo dos fantasmáticos, apresenta-se como uma necessária ferramenta de pesquisa no cinema e, de certa forma, sempre é feita nos documentários que contemplam uma historiografia do audiovisual. Que seria da história e mesmo do ensino do cinema se não pudesse refletir sobre as experiências malsucedidas de Welles, Coutinho, Gillian, Tan, entre tantos outros? É através dos rastros deixados por um filme fantasmático que se pode restituir a memória de um processo fílmico esquecido e até então invisível. Como lembra Jeanne Marie Gagnebin ${ }^{23}$, "o rastro inscreve a lembrança de uma presença que não existe mais e que sempre corre o risco de se apagar definitivamente" (2009, p. 44).

Em It's all true, parte-se dos rastros para tentar construir algo que seria mais próximo da obra que não foi feita e ficou inacabada. Em Cabra Marcado para Morrer, assim como em Shirkers, os rastros são apresentados por seus próprios realizadores, que refletiram sobre o que foi e o que não foi feito. Dessa maneira, eles recriam esses filmes de outra forma, o que gera uma circularidade, uma vez que o final é essa crítica genética de uma ideia de filme. Assim, o filme sobre o filme é a concretização da crítica genética como o único discurso acabado para além do filme original que não existe. No entanto, ao existir enquanto filme, o documentário historiográfico ganha também a possibilidade de poder construir sua própria documentação genética para buscar os seus próprios rastros. Nesse sentido, o filme fantasmático que não aconteceu passa a fazer parte da crítica genética do documentário sobre ele como seu rastro, o que resulta no filme sobre o filme e cria uma circularidade em que ambos são um o material genético do outro. Em Cabra marcado para morrer, observa-se essa circularidade em que um mesmo filme se evidencia como uma crítica genética de um ou dois

\footnotetext{
${ }^{20}$ Ostrower, F. Criatividade e processos de criação. Petrópolis: Vozes, 1987, p. 68.

${ }^{21}$ Benjamin, W. Magia e técnica, arte e política: ensaios sobre literatura e história da Cultura. São Paulo: Brasiliense, 1994.

${ }^{22}$ Ricoeur, P. Réflexion faite. Paris: Esprit, 1995.

${ }^{23}$ Gagnebin, J. M. Lembrar escrever esquecer. São Paulo: Editora 34, 2009, p. 44.
} 
filmes fantasmáticos e ganha maior centralidade porque o filme de referência não foi finalizado. Entretanto, uma vez que o documentário (1984) é realizado, o primeiro e o segundo filmes que não aconteceram (1964) tornam-se parte da crítica genética do filme posterior.

Essa dualidade, de certa forma, também é esgarçada em um filme experimental de Eduardo Coutinho, Um dia na vida (2010), que merece um estudo específico sobre ele, à luz da discussão aqui proposta, denunciado pela frase após o título na abertura do filme: "material gravado como pesquisa para um filme futuro" ${ }^{24}$. Nele há uma outra inversão, uma vez que o rascunho vira o filme pronto e o que se tem dele são justamente os rastros, já que o filme planejado foi abandonado e o rascunho assume-se como obra central. Durante 19 horas seguidas, Coutinho gravou, em $1^{\circ}$ e 2 de outubro de 2009, a programação da TV aberta brasileira de nove televisores e dessa gravação surgiu Um dia na Vida, sem qualquer voice over ou comentário, sem qualquer reflexão para além da própria montagem, que simula um grande zapping. O objetivo inicial de Coutinho era reencenar todas as imagens e todos os programas retratados nesse grande rascunho do que viria ser verdadeiramente o filme. Essa ideia foi rapidamente abandonada, pela complexidade e pelo custo de se filmar inúmeros cenários diferentes com um elenco muito grande. Evidenciando a distinção com a proposta anteriormente apresentada de filme esboço, que parte de um filme incompleto e que traz elementos de fora ou ineficientes para o filme, o rascunho compreende de fato uma imagem de ensaio, uma estrutura preliminar que, em sua totalidade, transforma-se na própria obra e que o evidenciaria como um filme de "notas" como aponta o crítico Carlos Alberto Mattos:

\begin{abstract}
O formato de "Apontamentos”, “Anotações” ou simplesmente "Notas” costuma ser adotado por cineastas de várias latitudes como uma forma de libertação. De alguma maneira, ele isenta o autor de cumprir exigências narrativas mais constituídas, seja da dramaturgia ficcional, seja da retórica documental. As "notas" cinematográficas permitem uma aproximação maior com o formato do ensaio, em que afirmações definitivas são substituídas por perguntas, ideias em andamento e raciocínios não necessariamente concludentes. (MATTOS, 2011).
\end{abstract}

É o que acontece com o rascunho feito por Coutinho com a montagem da programação de televisão que seria apenas a base para a encenação do filme em si, mas que se tornou o próprio filme. Pode-se dizer que a ideia original de Coutinho era o filme fantasmático e o rascunho era parte de seu material genético. Com a mudança de planos e aqui novamente se manifesta o coeficiente artístico de Duchamp, o rascunho se torna o próprio filme finalizado. Apesar de provavelmente mais incomum, poderia se configurar até mesmo uma quarta categoria, a de rascunhos de um filme fantasmático, das notas $^{25}$ que dialogam com as estratégias de Walter Benjamin no seu Passagens (2007), que se transformam, em sua totalidade, nas obras acabadas.

Um dia na Vida guarda também outro detalhe que interessa a essa discussão. Por ser uma costura de imagens de programas distintos de canais abertos de televisão, o filme naturalmente teria um grande problema com relação aos

\footnotetext{
${ }^{24} \mathrm{O}$ filme pode ser visto em https://www.youtube.com/watch?v=j9vYJ74JGzg.

${ }^{25}$ Há alguns exemplos de filmes de notas que poderiam ser analisados, posteriormente, nessa eventual quarta categoria e que dialogaria com a crítica genética. Alguns exemplos são: Anotações para Filmar Orestes na África (1970), de Pier Paolo Pasolini, e o Anotações de um Diretor (1969), de Federico Fellini.
} 
direitos autorais. Essa limitação cria uma espécie de apagamento do material genético do filme realizado anteriormente, rascunho. Para evitar complicações com a justiça, os créditos do filme só apontam o seu nome, a frase mencionada anteriormente e uma descrição de quando o filme foi feito. Não aparece nenhum nome de membro da equipe nem mesmo o do próprio Eduardo Coutinho. As exibições do filme eram, pelo mesmo motivo, clandestinas e sem cobrança de ingresso, para não configurar mais um problema jurídico com relação à pirataria. Desse modo, ironicamente, o rascunho promovido a filme, que ainda assim é referenciado em um filme fantasmático - que se suporia ter um diálogo maior com essa documentação genética por ser originariamente um rascunho -, é justamente o que mais tem dificuldade de publicizar esse material. Assim, a documentação genética do filme que está mais disponível são algumas gravações de exibições com a presença do diretor em mostras de cinema ou universidades, eventos não publicizados pelo mesmo problema legal e que trazem o testemunho de Coutinho sobre o processo fílmico.

Desse modo, Um dia na Vida inverte as polaridades dessa relação entre rascunho e obra final, entre material genético e obra acabada, configurando-se como a expressão máxima, para essa discussão, do embaralhamento entre essas definições que são proporcionados por um metafilme. Se por um lado, o filme experimental de Coutinho não pode representar um todo do que poderia vir a ser essa categoria por ser um exemplo muito particular, por outro ele impõe relações que ajudam a pensar essas fronteiras movediças tanto entre obra e material genético quanto entre obra acabada e filme fantasmático.

A obra que faz referência a um filme fantasmático é em maior ou menor grau um metafilme, um espaço fílmico indistinto, pois apresenta uma dupla função: ao mesmo tempo que é um estudo genético que evidencia rastros e processos de um filme fantasmático, ele próprio também pode ser analisado, enquanto obra pronta e realizada, pela crítica genética dos rastros que deixa depois de si. Também ocorre pela possibilidade de troca de lugares, em que um filme pode se constituir ao mesmo tempo como filme e material genético do outro ou de si próprio. Nesse sentido, os metafilmes feitos a partir de filmes fantasmáticos sugerem que podem oferecer uma maior complexidade para a crítica genética pelo seu processo que gera instabilidades nas definições e categorias por serem simultaneamente processo e obra. Esse caráter de metafilme talvez possa seguir Mitchell quando se refere às metaimagens de filmes que também adquirem um caráter selvagem, indistinto e indomável.

\section{Referências:}

ALBUQUERQUE, M. A.; MELO, L. A. Um dia na vida. Rio de Janeiro: 7 Letras, 2017.

BAUDELAIRE, C. Sobre a modernidade. Rio de janeiro: Paz e Terra, 1996.

BELLOUR, R. L'analyse du film. Paris: Albatros, 1979.

BENJAMIN, W. Magia e técnica, arte e política: ensaios sobre literatura e história da Cultura. São Paulo: Brasiliense, 1994.

BENJAMIN, W. Passagens. Belo Horizonte: UFMG, 2007.

BOGDANOVICH, P. Este é Orson Welles. São Paulo: Globo, 1995. 
CARVALHO, B. Obra prima de Welles redescobre o Brasil. Disponível em: https://www1.folha.uol.com.br/fsp/1994/6/06/ilustrada/9.html. Acesso em 10 de out. 2021.

DUCHAMP, M. O ato criador. In: Battcock, G. A Nova Arte. São Paulo: Perspectiva, 2002. p. 71-74.

GAGNEBIN, J. M. Lembrar escrever esquecer. São Paulo: Editora 34, 2009.

MATTOS, Carlos Alberto. Apontamentos sobre os 'Appunti' de Pasolini. Disponível em: https://carmattos.com/2011/01/13/apontamentos-sobre-os-appunti-de-pasolini/. Acesso em 9 dez. 2021.

MITCHELL, W.J. T. Picture Theory: essays on verbal and visual representation. 1 ed. Chicago: Chicago Press, 1994.

MUANIS, F. As metaimagens na televisão contemporânea: autorreferência, temporalidade, imersão. Curitiba: Appris, 2018.

MUANIS, F. Zapping como conteúdo e espectatorialidade: Tá no ar: a TV na TV e Um dia na Vida. In: Pelegrini, C.; Muanis, F. Perspectivas do audiovisual contemporâneo: urgências, conteúdos e espaços. Juiz de Fora: UFJF, p. 165-179.

OSTROWER, F. Criatividade e processos de criação. Petrópolis: Vozes, 1987.

RICOEUR, P. Réflexion faite. Paris: Esprit, 1995.

SALLES, C. A. Gesto inacabado: processo de criação artística. São Paulo: FAPESP: Annablume, 1998.

SALLES, C. A. Imagens em construção. In: Revista Olhar. Ano 2, no 4, Dez; 2000.

Xavier, I. O discurso cinematográfico: a opacidade e a transparência. Rio de Janeiro: Paz e Terra, 1977.

\section{Referências fulmicas:}

Anotações de um Diretor (1969) Direção: Federico Fellini. Itália.

Anotações para Filmar Orestes na África (1970). Direção: Pier Paolo Pasolini. Itália.

Cabra Marcado para Morrer (1984). Direção: Eduardo Coutinho. Brasil

Don Quixote de Orson Welles (1992). Direção: Orson Welles e Jess Franco. Estados Unidos.

Forofina, um filme a ser feito (2020). Direção Sylvio Lanna e Cavi Borges. Brasil.

It's all true - Based on an unfinished film by Orson Welles (1993). Direção: Bill Krohn, Myron Meisel, Orson Welles e Richard Wilson. Estados Unidos.

Já visto, jamais visto (2013). Direção: Andrea Tonacci. Brasil. 
revista de crítica genética

O roteiro do gravador (1967). Direção: Sylvio Lanna. Brasil.

Onde a Terra Acaba (2003). Direção: Sérgio Machado. Brasil.

Perdido em La Mancha (2002). Direção: Keith Fulton e Louis Pepe. Estados Unidos.

Que viva México! (1932). Direção Sergei Eisenstein, México.

Shirkers - O Filme Roubado (2018). Direção: Sandi Tan. Estados Unidos; Reino Unido.

The Other side of the Wind (2018). Direção: Orson Welles. Estados Unidos.

Um dia na vida (2010). Direção: Eduardo Coutinho. Brasil. 